Type of the Paper (Article.)

\title{
Cyclone Evacuation Route Identification Using GIS for Coastal Communities in Mirzaganj Union, Patuakhali, Bangladesh
}

\author{
Maruf Billah ${ }^{1 *}$, Sraboni Sarker ${ }^{2}$ and Mehedi Ahmed Ansary ${ }^{2}$, \\ 1 Graduate student, Institute of Water and Flood Management, BUET, Dhaka, Bangladesh; marufbillah413@gmail.com \\ 2 Undergraduate student, Faculty of Disaster Management, PSTU, Patuakhali, Bangladesh; \\ srabonisarker8829@gmail.com \\ 2 Professor, Department of Civil Engineering, BUET, Dhaka, Bangladesh; ansary@ ce.buet.ac.bd
}

\section{* Correspondence: marufbillah413@gmail.com; Tel.: +88-017-614-28534}

Received: date; Accepted: date; Published: date

\begin{abstract}
Evacuation is the primary and most important preparedness initiative to save people from the devastating effects of a cyclone. For proper evacuation, a route is specifically chosen that will play a role during cyclones. In this study, Geographic information system has been applied for evacuation route planning for Mirzaganj Union, Patuakhali, Bangladesh. The study is based on questionnaire surveys; direct observation and literature review on the existing sheltering system and develops an evacuation route using the shortest distance analysis. This study provides us an idea how we can manage our population to find out suitable nearby shelters and the limitations that we should focused on. The result shows that only $12 \%$ of the total population gets shelter opportunity with the existing official shelter capacity by identifying evacuation route with the shortest distance and the shortest time needed. Shortest distance and time have been calculated for each cyclone shelters. If we consider the low vulnerable infrastructures as shelter, $75 \%$ of the total population can be accommodated. This study demonstrates the utilization of an ideal evacuation route planning in the coastal parts of Bangladesh.
\end{abstract}

Keywords: Cyclone, Cyclone Shelter, Evacuation, Network Analysis, Bangladesh

\section{Introduction}

Different natural disasters, such as cyclones, droughts, and floods are increasing globally in recent years (Khan \& Rahman, 2007; Solomon, Qin, Manning, Averyt, \& Marquis, 2007). Cyclones are considered as the world's leading natural disasters that even exceed the effects of earthquakes (Benavente, Del Río, Gracia, \& Martínez-del-Pozo, 2006; Dube, Rao, Sinha, Murty, \& Bahulayan, 1997; Murty \& El-Sabh, 1992; Zerger, Smith, Hunter, \& Jones, 2002). Bangladesh is the most vulnerable area to cyclones because of its geographical location at the triangular shaped head of the Bay of Bengal (Murty \& Neralla, 1992), due to its high population density and the absence of effective coastal protection systems. In the pre-monsoon (April-May) or postmonsoon (October-November) seasons, at least one major tropical cyclone hit the Bangladesh coastal region each year (C. E. Haque, 1997; Mooley, 1980). Approximately one-tenth of global tropical cyclones occur in the Bay of Bengal (Choudhury, 1994). About one-sixth of the total cyclones developing in the Bay of Bengal make landfall on the coastal parts of Bangladesh (Quadir \& Iqbal, 2008). If a cyclone occurs in tropical regions, it is known as a tropical cyclone. Cyclones occurring elsewhere are known as extra-tropical cyclones (Fritz et al., 2007, 2008).

Existing literature shows that several devastating cyclones have stuck Bangladesh in 1822, 1876, 1961, 1965, 1970, 1991 and 2007 (Blaikie, Cannon, Davis, \& Wisner, 2014; Dube et al., 1997). Among the 64 districts of Bangladesh, 19 are the located in the coastal areas. The population of this area is near about 36.8 million and 
more than half of the population (52\%) are poor and about $41 \%$ is under the age of 15 (R. M. Islam, 2008). In spite of the poverty and being the most vulnerable to different kinds of coastal disasters, with their traditional indigenous knowledge and perceptions, these coastal people are coping with different kinds of disasters and passing their lives with relentless struggle (Parvin, Takahashi, \& Shaw, 2008). Two destructive cyclones occurred in 1970 and 1991, with more than 500000 and 140000 causalities, respectively. However, in the last 20 years, Bangladesh has been able to reduce deaths and injuries from the cyclones. For example, the recent major cyclones like Sidr of 2007 and Aila of 2009 caused 3406 and 190 deaths only, about a 100-fold reduction of lives compared to the deadliest 1970 and 1991 cyclones (A. Ali, 1996; Haider, Rahman, \& Huq, 1991 ; U. Haque et al., 2012; Bimal Kanti Paul, 2009a).

As controlling the occurrence of natural disasters is almost impossible, the loss of life and property from these disasters can be minimized or prevented if proper precautions and preventive initiatives are taken timely. For saving human lives the fictitious solutions is to build the habitation above the surge level and construct them strong enough to resist high wind speed and the surges (Mallick, Rahaman, \& Vogt, 2011). Nevertheless, the majority of coastal residents are living under poverty level in poorly constructed houses that are vulnerable to cyclone (Bimal K. Paul, Rashid, Islam, \& Hunt, 2010). Existing literatures shows the importance of constructing raised platforms, reinforcement of homestead structures, overall cyclone proof houses in reducing casualties (Ahmed, Haq, Nasreen, \& Hassan, 2015). Besides, focus has been given on infrastructures stability and different infrastructures types to respond to cyclone like temple shaped house and elevated houses (S. K. Paul \& Routray, 2011). Locations and pattern of settlements are the most important factor to decrease vulnerability of the coastal people. Scattered settlements in the coastal areas are more susceptible to cyclone (Alam \& Collins, 2010).In the recent past, GIS and RS technology have increased the accessibility in the cyclone occurrence stage in order to develop map and assess the vulnerability of lives and infrastructures of cyclone-prone areas (Chisty, Islam, \& Samad, n.d.; Rana, Gunasekara, Hazarika, Samarakoon, \& Siddiquee, 2010). In developing countries it is badly in need to develop good quality and quantity GIS database for evacuation management. GIS and RS technology can contribute the management process in other hazard prone area like drought, storm surge, flood, land slide, salinity intrusion. So, there is a scope to work with the application of GIS and RS in disaster management especially in the country like Bangladesh.

The next solution is evacuation of the coastal people to the high ground above the surge level (Mallick et al., 2011). Evacuation is considered as the primary preparedness action against any large-scale disasters like the cyclone. An early warning system also plays a valuable role in the evacuation of vulnerable people during the occurrence of the disasters along with minimizing the loss (Dhar \& Ansary, 2012). The effective early warning system provided by the government in advance of Cyclone Sidr, Aila, Mohasen, Komen, Roanu, Mora in 2007, 2009, 2013, 2015, 2016 and 2017 enabled successful evacuation of coastal communities that resulted in fewer than expected deaths. Besides the early warning systems, different activities like construction of cyclone shelters, embankment, and timely evacuation have contributed to decreasing the death rates in the coastal areas (S. S. Ali, Rahman, \& Chowdhury, 2012; U. Haque et al., 2012).In spite of the improvements in early warning systems, pre-cyclone evacuation remains a challenge (Dhar \& Ansary, 2012). Some factors like illiteracy, lack of awareness, structural vulnerability and communication problems including poor road networks are the obstacles that hamper the evacuation system. Instead of moving to cyclone shelters, people in coastal areas still believe in a wait-and-see approach (Bern et al., 1993; Chowdhury, Bhuyia, Choudhury, \& Sen, 1993; S. K. Paul $\&$ Routray, 2013). On the other hand, access to road network, distance of cyclone shelters from the homestead, and access to cyclone shelters are the factors that influence the evacuation decision (S. K. Paul, 2014). 
Cyclone shelters play an important role during the evacuation. It has been estimated that around 1.5 million people have been evacuated by CPP (Cyclone Preparedness) volunteers to the multi-purpose cyclone shelters (MPCS) when Cyclone Sidr hit the coastal parts of Bangladesh in 2007 (Nateque Mahmood, Prasad Dhakal, \& Keast, 2014; Bimal Kanti Paul, 2009b). Before the destructive cyclone of 2007, Bangladesh had only 1500 cyclone shelters in the coastal districts as the infrastructural support during cyclone. After Sidr, Bangladesh Government has constructed around 2000 new cyclone shelters for the population of the coastal belt. The World Bank surveyed and further estimated that there is still a need for 5500 new MPCS (Multi-Purpose Cyclone Shelter) facilities for the purpose of a disaster management strategy (A. S. Islam, Bala, Hussain, Hossain, \& Rahman, 2010; Nateque Mahmood et al., 2014). GIS-based map has been produced to know about the coverage area of a shelter and need for new shelters (Mallick, 2014).

Despite of completing these initiatives, the evacuation route to cyclone shelters from any community remains a challenge and is not well defined. People living in the coastal areas are not aware of the appropriate evacuation plan and route during cyclones. They can't take the decision during cyclones in which shelter they should go and which shelter is within their reachable distance. It is common that computing shortest paths over a network is an important task for evacuation. With the development of geographic information systems (GIS) technology, network and transportation analyses within a GIS environment have become a common practice in many application areas. Different factors like easy accessibility of the community people to the shelter with maximum walking distance for an individual is restricted to 2.25 kilometers, covering the entire population of the region by producing safe zones and evacuation zones, suitability of the shelters for other community activities are needed to follow (Dalal, Mohapatra, \& Mitra, 2007; Gupta, Gupta, Gupta, \& Gupta, n.d.). There exists digitized road map including road class, distance and shortest optimum route (Devlin, McDonnell, \& Ward, 2008).Many network flow model including logistics coordination model has been built for identifying optimal lane-based evacuation routing plans in a complex road network by using mixed-integer programming solver (Cova \& Johnson, 2003; Murray-Tuite \& Mahmassani, 2003; Yi \& Özdamar, 2007). There exist gaps in the above papers for identifying the shortest distance analysis which is needed during an evacuation process. In the reviewed papers, shortest distance have been analyzed in a map for a vast area without presenting numerical values of the distance from evacuation point to the shelters. Even how many people could be evacuated from each point has not been defined. As Bangladesh is a cyclone prone country, proper evacuation route is a need to reduce the number of affected people. This paper presents an evacuation route planning for Mirjaganj union of Patuakhali, Bangladesh using the shortest distance analysis for each shelter as well as shelter capacity analysis.

\section{Materials and Methods}

The research is based on both secondary and primary data collected through household questionnaire survey. The total sample size for the household questionnaire survey has been considered 3220 households. In questionnaire survey different variables have been used to analysis the existing structural condition against cyclone hazard in which they live in. Different variables have been discussed in details in table 2. After collecting the data, ArcGIS10.1 and Microsoft excel have been used to analyze the collected data. ArcGIS10.1 has been used in developing maps, geographic data analysis, editing, data management, and geo-processing activities and also been used in finding the closest shelter facility location, using shortest path analysis method. A realistic evacuation planning with the shortest route to shelters has been proposed in this study and has been validated using field data.

\subsection{Study Area}


Figure 1(a) shows the past records of cyclones that hit Bangladesh. Among the Unions of Patuakhali district, Mirzaganj Union is one of the most vulnerable unions to cyclone hazard. Area of Mirzaganj Union is 34 square $\mathrm{km}$, located in between $22^{\circ} 13^{\prime}$ and $22^{\circ} 29^{\prime}$ north latitudes and in between $90^{\circ} 08^{\prime}$ and $90^{\circ} 19^{\prime}$ east longitudes. Total amount of road is near about 90 kilometers, among these paved roads are $20 \mathrm{~km}$, herring bond roads are $10 \mathrm{~km}$ and earthen roads are $70 \mathrm{~km}$. There are 7 secondary schools, 23 primary schools, and $16 \mathrm{madrasa}$. Main source of income is agriculture with 8527 acres of cultivable land. Due to the geographical location that union has been severely affected by 2007 cyclone Sidr and 2009 Aila. Figure 1(b) shows the location of the union.

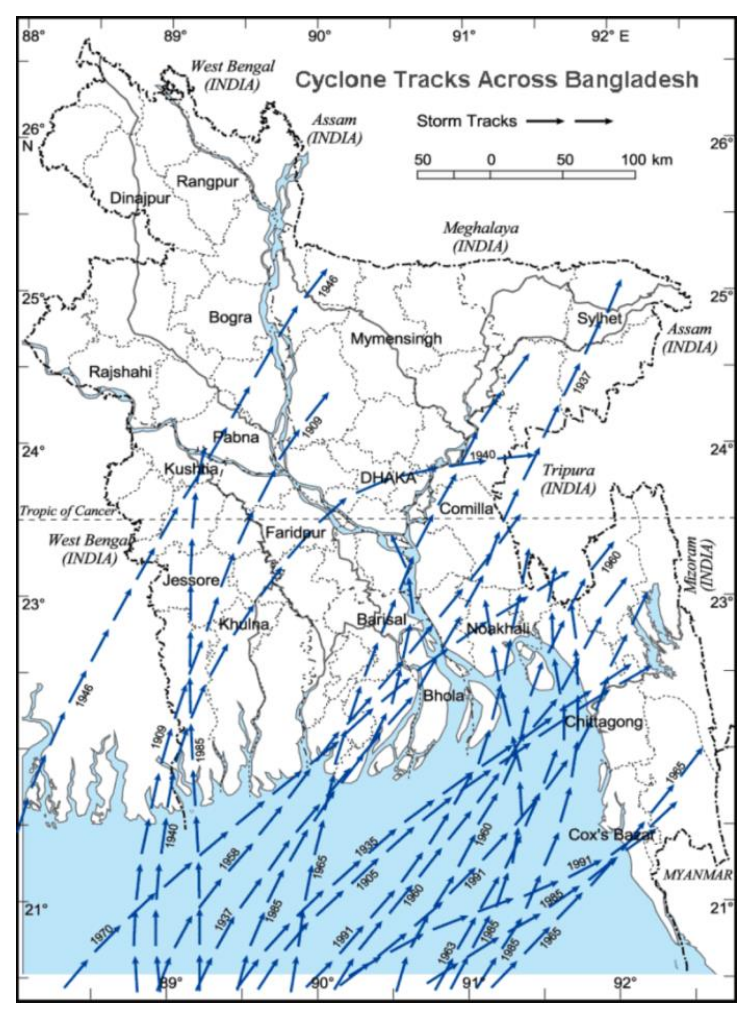

(a)

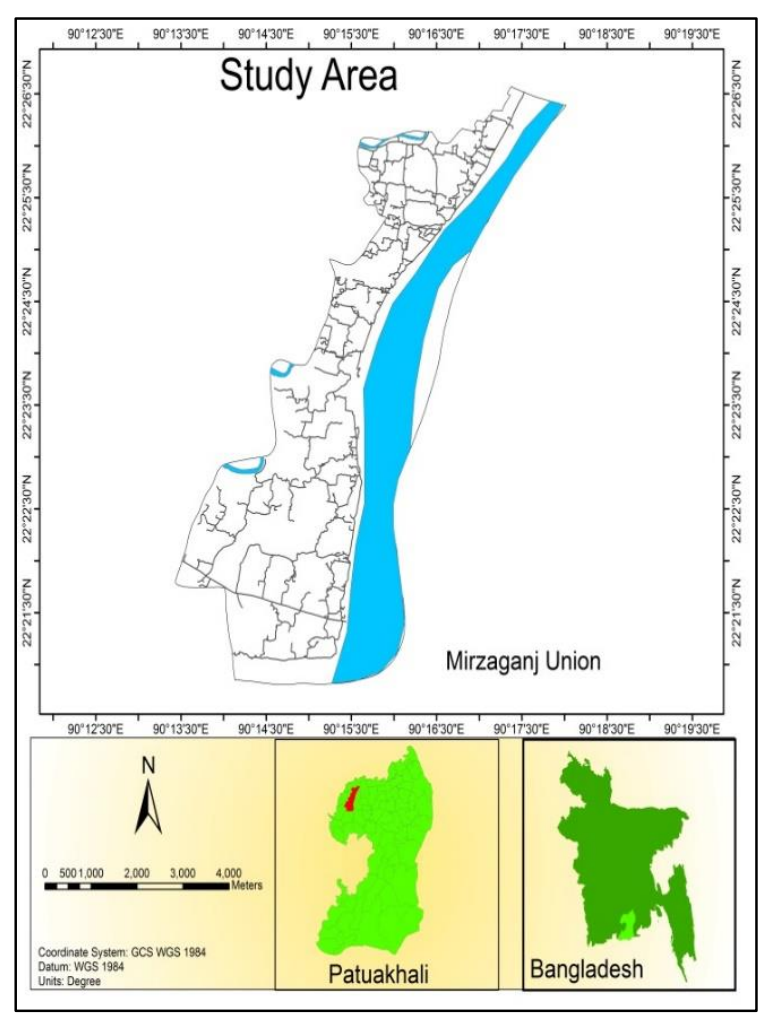

(b)

Figure1: (a) Cyclone Tracks in Bangladesh and (b) Study Area (Mirzaganj Union)

\section{Results and Discussion}

Mirzaganj union is bounded by the Payra River on the south and east, the Srimanta River on the west as can be seen in Figure 1(b).According to the Jatiyo Batayon, and there are 11 villages in this union. Total population is 22100. Among them male is 11073 (50.10\%), female is 11027 (49.89\%). After surveying 3220 households, it has been found that average 7 people live each in household. The literacy rate of the union is $70 \%$ including 13033 voters. Most of the people are farmers and small shopkeepers.

\subsection{Condition of the Existing Cyclone Shelters and Infrastructures}

In Mirzaganj area there are only two usable cyclone shelters (Figure 2). The shelters are designed to withstand a wind speed of $260 \mathrm{~km} /$ hour and placed on a higher ground to avoid the effect of the maximum 
expected surge level. Shelters have been constructed with the required facilities (Table 1). The shelters buildings are primarily used as schools. Shelters are designed in such a way that both human and livestock can take refuge there.

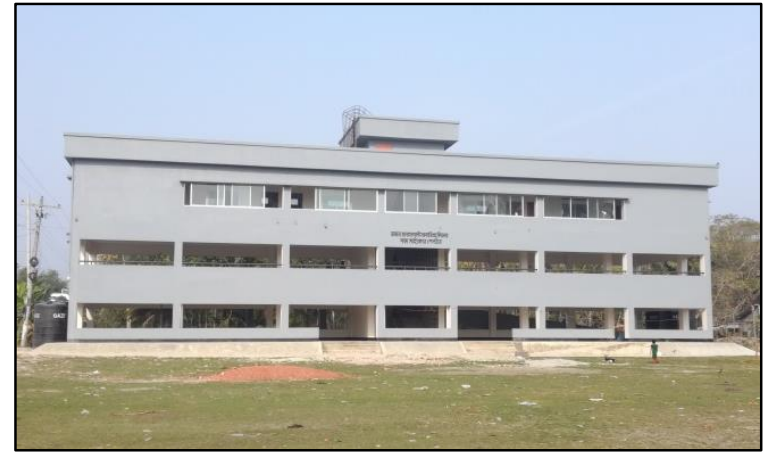

(a)

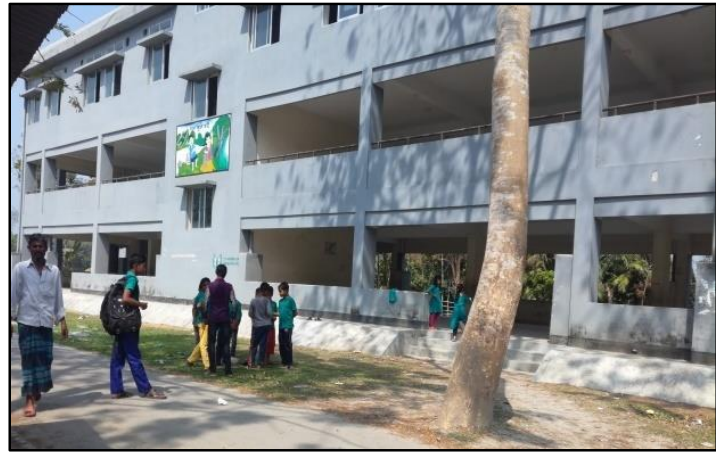

(b)

Figure 2: (a) Cyclone Shelter no 1; (b) Cyclone Shelter no 2.

Table 1: Details about Existing Cyclone Shelters

\begin{tabular}{lll}
$\begin{array}{l}\text { Different } \\
\text { Attributes }\end{array}$ & Cyclone Shelter no 1 & Cyclone Shelter no 2 \\
\hline Name & Vazna Monoharkhali Govt. Primary School & Vikakhali Govt. Primary School cum \\
& cum Cyclone Shelter & Cyclone Shelter
\end{tabular}

Location

5 minutes walking time from Mirzaganj ferry

5 minutes walking time from Vikakhali ghat ferry ghat

Date completion January, 2018

February, 2014

Type of Shelter LGED type 3

Source of Fund GoB and World Bank

Structure

- Three storied building

- Open ground-floor structure to avoid flooding from the storm surges

- Open first floor with tube-well facilities is kept for cattle with ramp to move on it.

- Second floor with room and bathroom facilities for human shelter 
Total Room

Facilities:

Livestock

Capacity
In total 6 rooms, 4 large size rooms and 2 extra rooms with attached bathroom for pregnant women and children.

-Total 4 bathrooms (2 attached)

-Two motors for drinking water

-Four tube-wells

-4 water tanks capacity with 2000 liters

-4 water tanks capacity with 7000 liters (especially in cyclone shelter no 1)

-Solar system is installed

-Rain water harvesting system (especially in cyclone shelter no 1)

Source: Field Survey, May 2018.

The official capacity of each cyclone shelter is 1300 people. A large amount of people (about 19000) have to stay at their own place due to lack of space in the shelters. That's why a survey has been conducted on the condition of households and their vulnerability to test if they can withstand cyclone or not. The survey has been conducted through a semi-structured questionnaire to measure the vulnerability of the existing households. Table 2 presents the criteria used in the questionnaire to assess the vulnerability of the infrastructures. Scoring has been done depending on the criteria. There are individual houses, schools, mosques and others structures of the assessed infrastructures, some of which are shown in Figure 3.

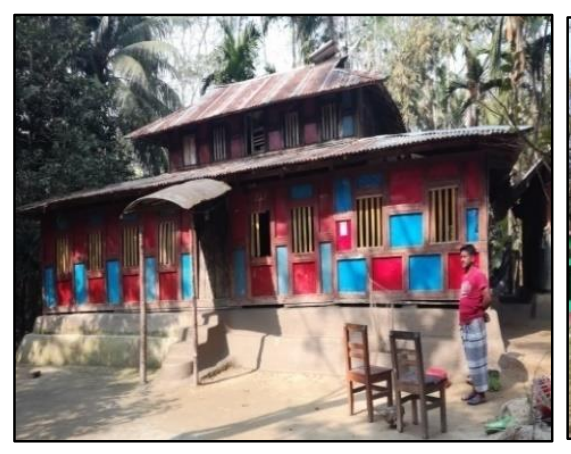

(a)

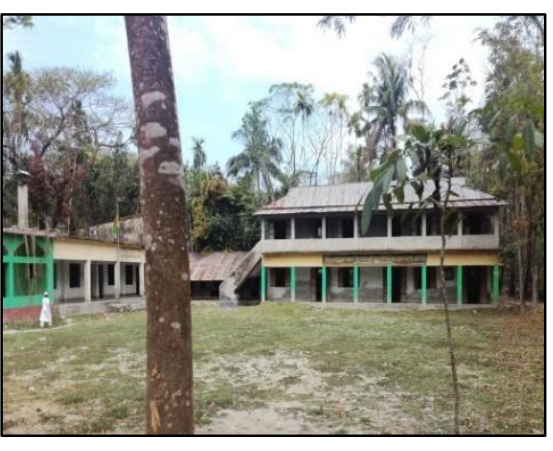

(b)

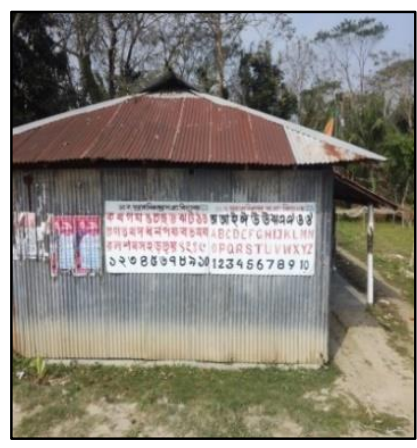

(c)

Figure3: (a) Homestead; (b) Mosque and Madrasa and (c) School 
Table 2: Infrastructure Vulnerability Scoring

\begin{tabular}{|c|c|c|}
\hline Criteria & Sub-Criteria & Score \\
\hline \multirow[t]{2}{*}{ Width of the house is perpendicular to nearest river's length } & Yes & 1 \\
\hline & No & 4 \\
\hline \multirow[t]{2}{*}{ House is in the safe distance from the biggest trees } & Yes & 1 \\
\hline & No & 4 \\
\hline \multirow[t]{2}{*}{ There is sufficient amount of trees around the house } & Yes & 1 \\
\hline & No & 4 \\
\hline \multirow[t]{2}{*}{ Which type of house that is? } & Concrete & 1 \\
\hline & Tin & 5 \\
\hline \multirow[t]{2}{*}{ Size of house(floor area) } & Square & 1 \\
\hline & Rectangular or L shape & 4 \\
\hline \multirow[t]{2}{*}{ Plinth level } & $4^{\prime}$ & 1 \\
\hline & Less than $4^{\prime}$ & 4 \\
\hline \multirow[t]{2}{*}{ Ridge level } & High & 1 \\
\hline & Low & 4 \\
\hline \multirow[t]{3}{*}{ Wall } & Concrete & 1 \\
\hline & Wood & 3 \\
\hline & Tin & 5 \\
\hline \multirow[t]{2}{*}{ 'J' hook presence } & Yes & 1 \\
\hline & No & 5 \\
\hline \multirow[t]{3}{*}{ Post of house } & Concrete & 1 \\
\hline & Bamboo & 2 \\
\hline & Wood & 3 \\
\hline
\end{tabular}


The thickness of tin

Window

Door
Above $0.35 \mathrm{~mm}$

Less than $0.35 \mathrm{~mm}$

Size above $4^{\prime * 4^{\prime}}$

Less than $4^{\prime *} 4^{\prime}$

Size above $3.6^{\prime *} 6.6^{\prime}$

Less than $3.6^{\prime *} 6.6^{\prime}$
2

5

2

5

1

*Analysis has been based on criteria collected from "Construction Manual on Shelters for Cyclone-Prone Coastal Areas of Bangladesh" proposed by Disaster Management Bureau (DMB) of the Ministry of and Disaster Management and Relief (MODMR) and the Bangladesh University of Engineering \& Technology (BUET).

Figure 4(a) shows the vulnerability map of the studied union. Figure 4(b) indicates that among 3220 surveyed infrastructures 24 are with very low vulnerability (1\%), 145 are with low vulnerability (4\%), 1114 are with moderate vulnerability (35\%), 1887 are with high vulnerability (59\%) and 50 are with very high vulnerability (1\%). It also shows that about $5 \%$ households are with low to very low vulnerable to cyclone and $95 \%$ households are not strong enough to withstand cyclone.

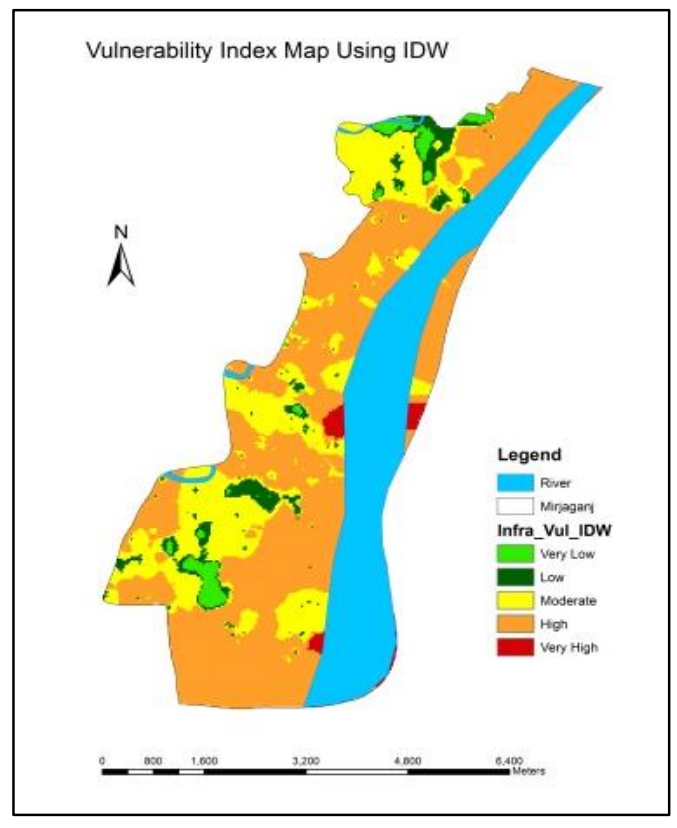

(a)

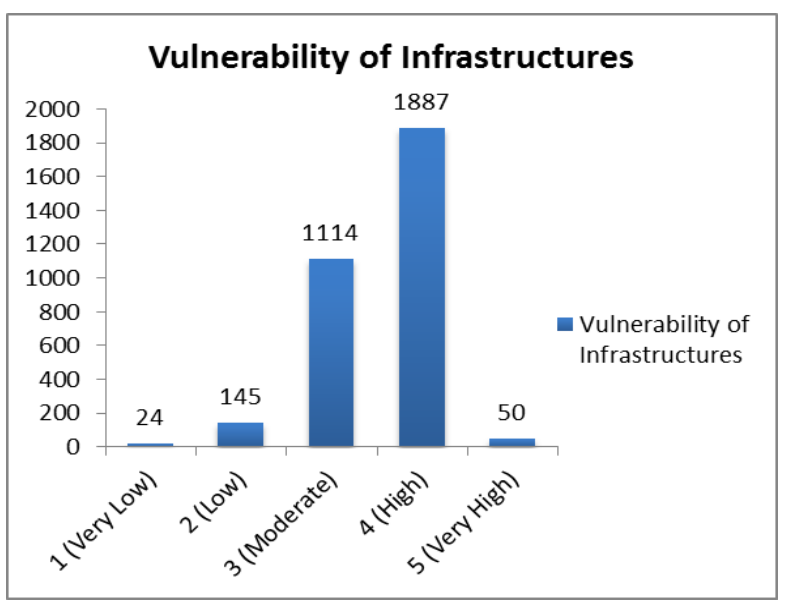

(b)

Figure 4: (a) Map of vulnerability of infrastructures; (b) Infrastructures with various vulnerability ranges.

\subsection{Existing Road Network System}

Network Analysis in GIS is based on graph theory and topology. It is often used to find solutions to transportation problems by using either vector or raster models to represent the real world. The vector-based model appears to be more suited to analysis of precisely defined paths such as roads and rivers (Bukholm, Husdal, Nesland, Langerød, \& Bukholm, 2003). For a proper evacuation, a good road infrastructure is needed. 
Road network in coastal villages are still in rudimentary stage and path to the cyclone shelters remain unsafe prior to the landfall of cyclone because of excessive rainfall, high wind velocity, flooded terrain and tidal waves. Most of the time, roads are damaged by storm surge and make an obstacle for community people from going to safer places.

Figure 5(a) presents the map of road types of Mirzaganj Union. In this map three types of roads (earthen road, herring bond road, and paved road) have been shown. In Figure 5, three types of roads and lengths of the particular roads are presented. Among those 72.47 kilometers are earthen road (71\%), 24.49 kilometers are paved roads $(24 \%)$ and 5.4 kilometers are herring bond roads $(5 \%)$. It can be clearly seen that half of the total road is of earthen type and is the most vulnerable during a cyclone. For this reason during a cyclone earthen road may be a snag for community people for evacuation. Besides width of roads play an important role during evacuation. Wider roads allow more people to evacuate than congested roads.

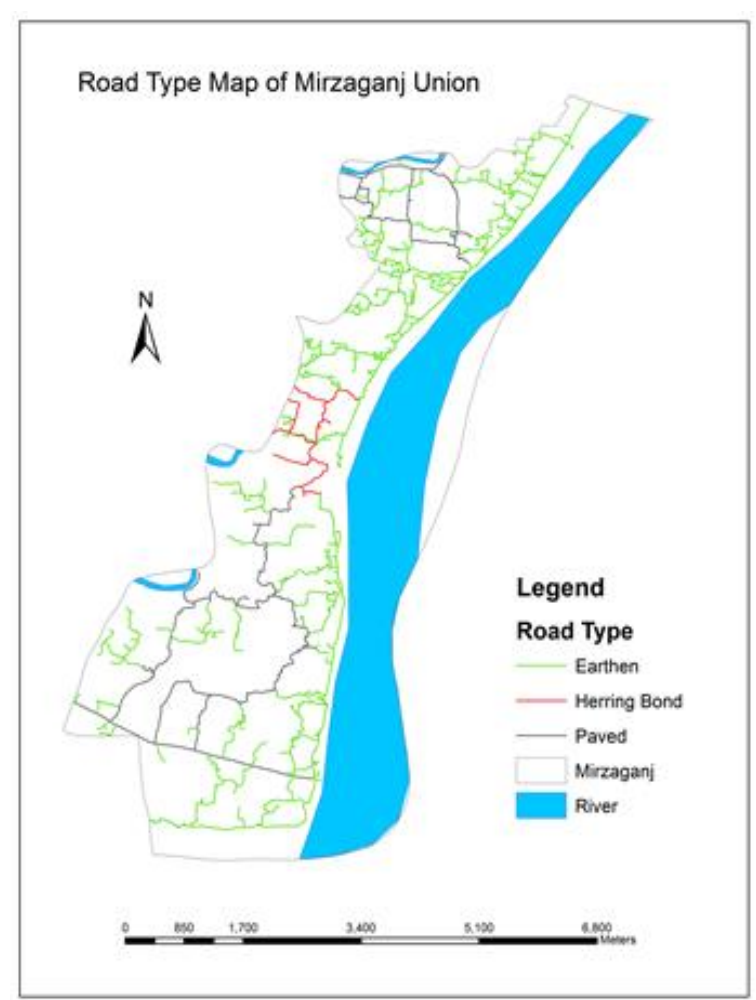

(a)

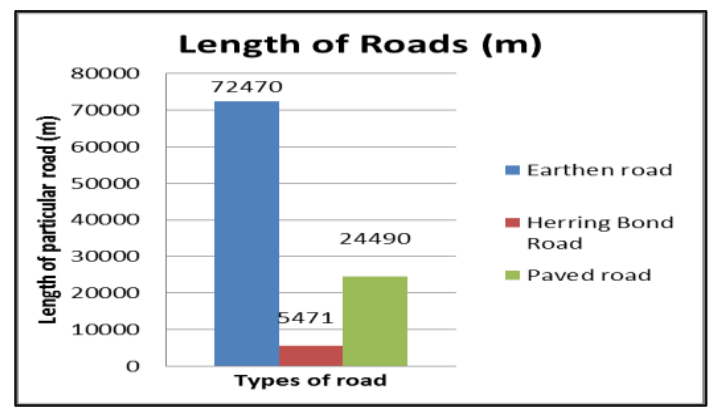

(b)

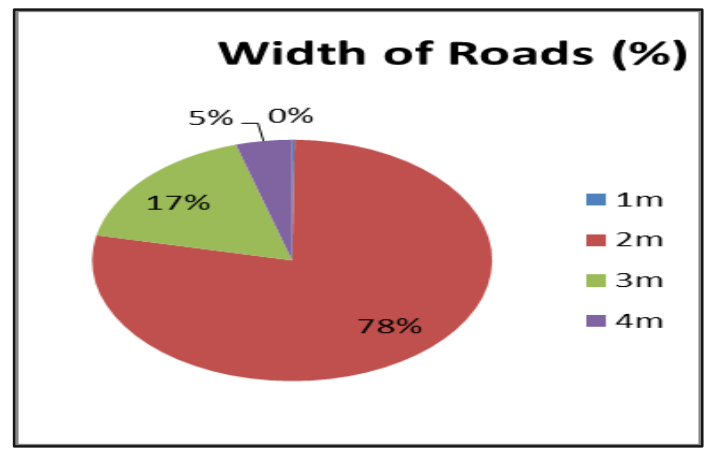

Figure 5: (a) Road types of the Union; (b) Length of Roads in meters; (c) Width of Roads in percentages.

\subsection{Evacuation Route Analysis}

It has been already mentioned that there is no delineated evacuation plan in this union. While warning system of Bangladesh is improving day by day but evacuation remains as a challenge because of lack of government plan. If there is a shortest route earmarked for every dense area, people will be able to reach to the cyclone shelters properly. Before analyzing the shortest distance we have considered cyclone shelters as inlet where people will take refuge and in every dense area we assumed a point as outlet from where maximum 
people can gather and evacuate to the shelters. In this study, based on the accessibility to shelters and distance from the main roads, 21 evacuation points (outlets) are marked around the study area. These outlets are situated at or near to the significant roads.

Figure 6(a) shows the outlets in the densely populated areas from where maximum people can be evacuated to the shelters and 6(b) shows the shortest distance from every outlet to the nearest shelter. From every outlet to inlet shortest distance has been analyzed using Network Analysis Tool in ArcGIS 10. As there are two inlets, the total outlets are divided into two areas as can be seen in Figure 6. Green colored routes are presented as the shortest distances to cyclone shelter no 1 and red colored routes are presented as the shortest distances to cyclone shelter no 2 .

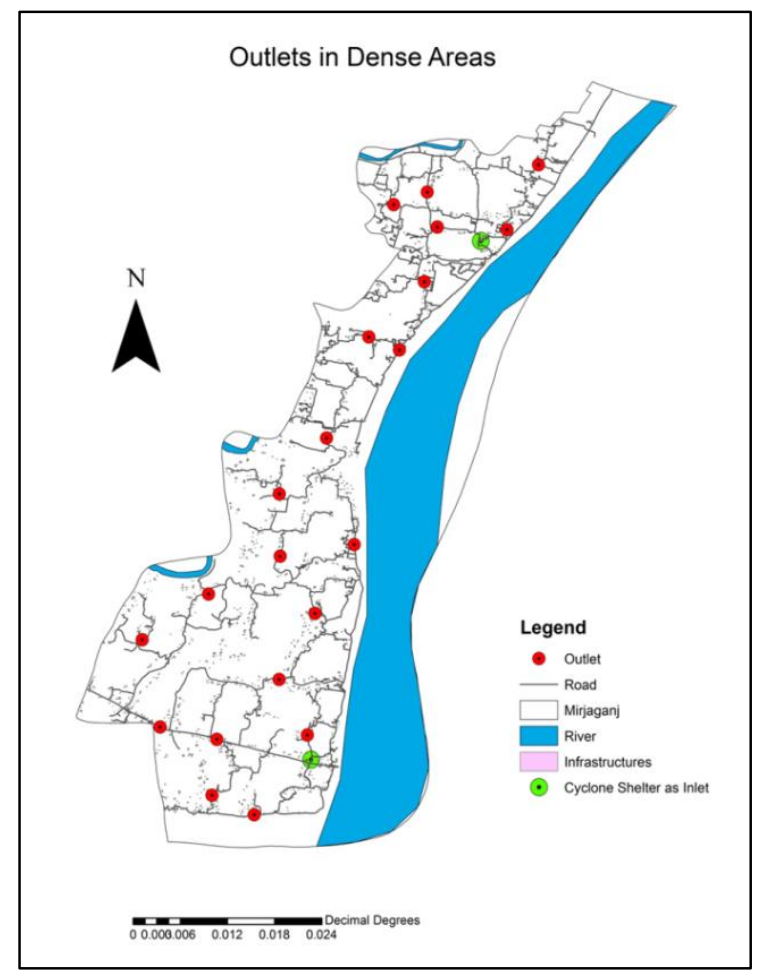

(a)

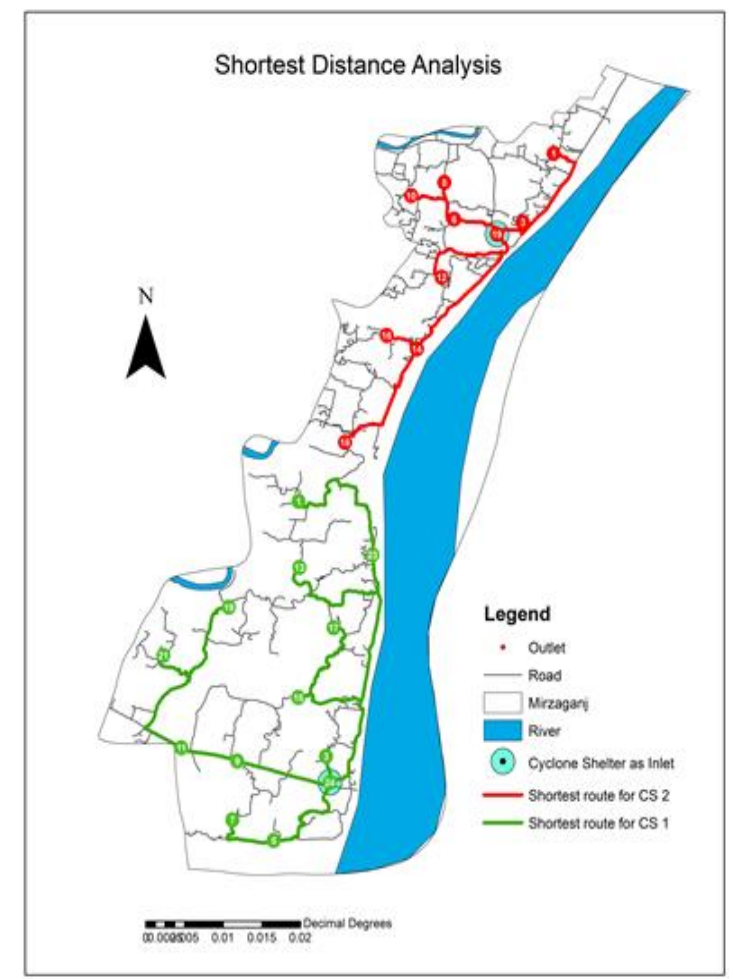

(b)

Figure 6: Outlets and Inlets in Mirzganj Union (a), Shortest Distance Analysis of Mirzaganj Union (b)

Figure 7 presents the shortest distances from the different outlets to the shelters. The shortest distances for shelter no 1 are colored with green and the shortest distances for shelter 2 are colored with red. For shelter no 1, the shortest distance is 351 meters from outlet which is marked as CS1O3 (which means, CS1 is Cyclone shelter 1 and $\mathrm{O} 3$ is outlet 3 ) and for shelters no 2, the shortest distance is 518 meters from outlet which is marked as CS2O3.

In Figure 8 buffer zones have been developed keeping the outlets as the centers with $600 \mathrm{~m}$ radius to assume how many people are covered for evacuation. It shows that 16465 people (based on field survey) can be evacuated to shelters, which is $70 \%$ of total population. Time is also an important factor for real time evacuation. The shortest distance along with the shortest time can be the best solution for assuming how much time it will take to move to the shelters through the shortest distance from each outlet. However, from the field 
survey we have found that during cyclone different types of factors like connectivity nodes and bent nodes may affect the travel time.

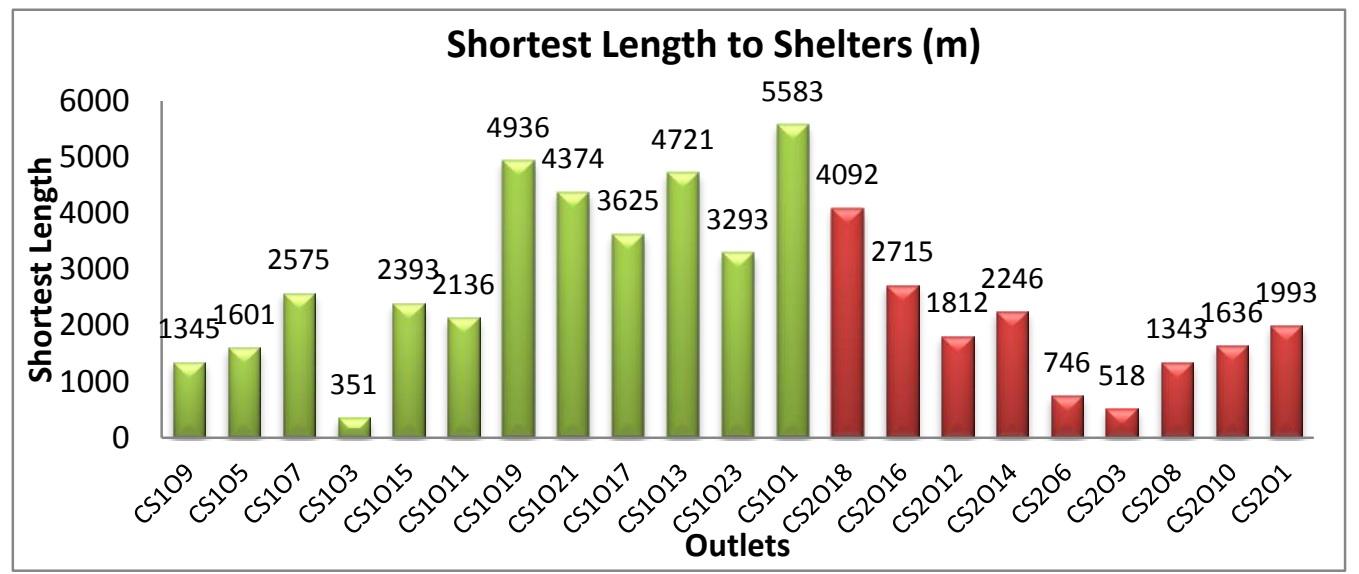

Figure 7: Shortest length to Shelters

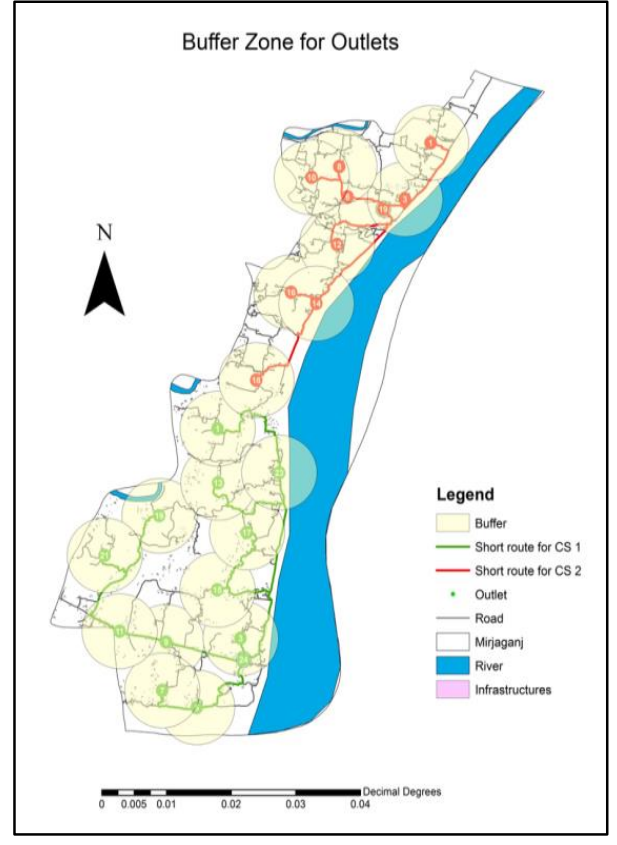

(a)

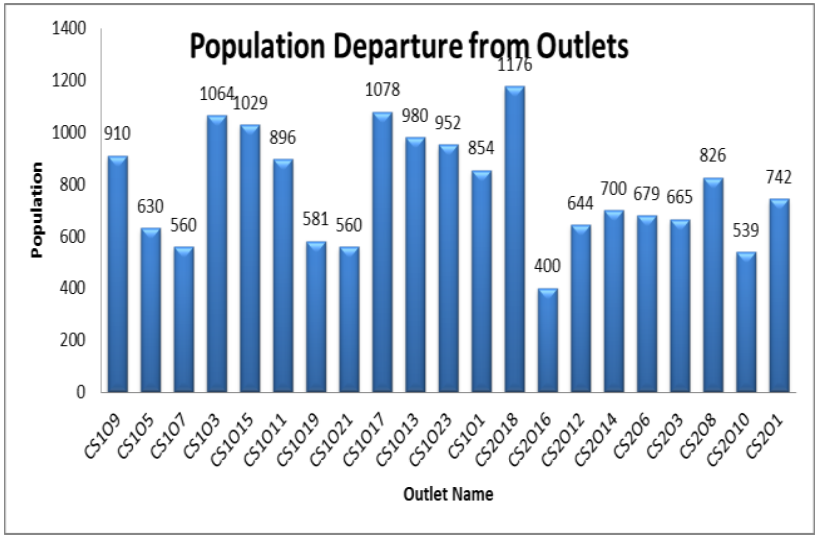

(b)

Figure8: Buffer Zones for Outlets (a), People departing from each Outlet in Bar Chart (b).

Figure 9shows the various bent nodes and connectivity nodes of the road network that cause delays. The placement of bent nodes and connectivity nodes are put in those places from where people would take turn to other roads and where roads have crossed each other.

In Table 3, we have developed a map of bent node network in which we have assumed 2 seconds delay for the bent nodes and in the map of connectivity node network we have assumed 4 seconds delay for the connectivity node for every shortest length to shelter. In Table 3, walking distance has been assumed 3.6 kilometers per hour or 60 meters per minute. 


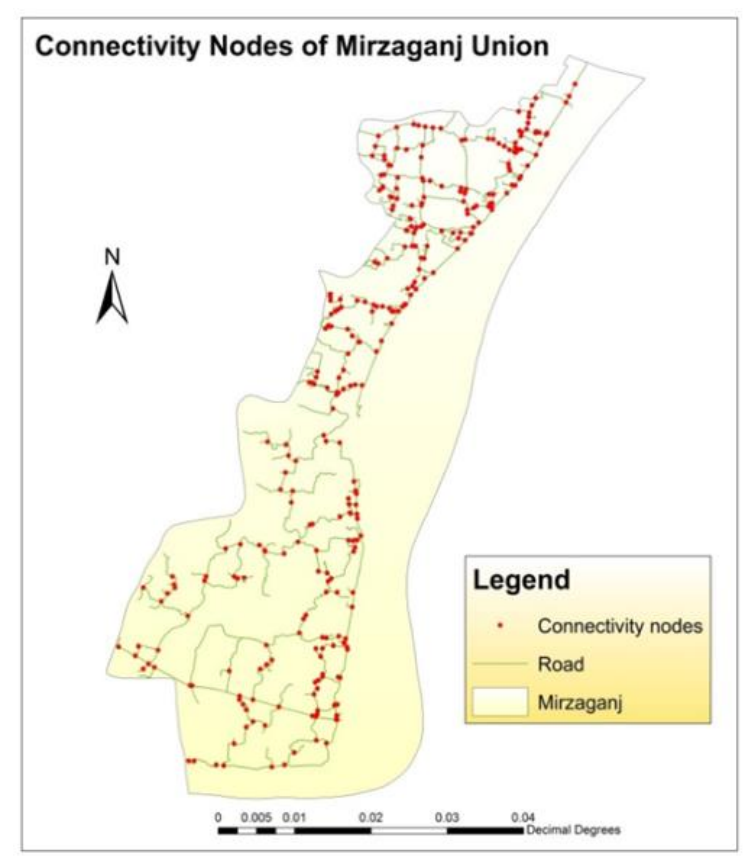

(a)

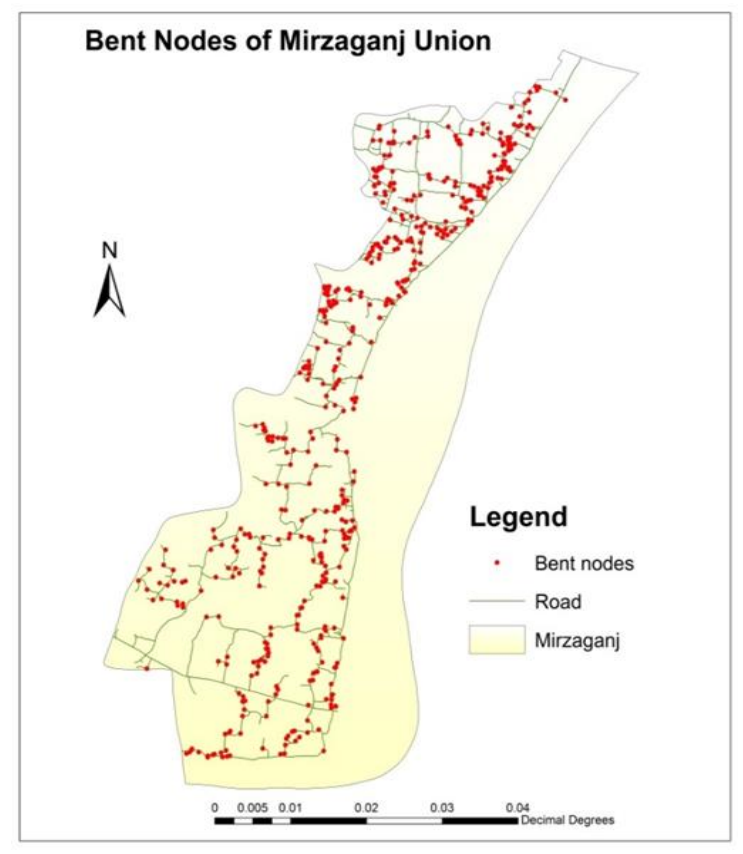

(b)

Figure 9: Connectivity Nodes Map (a) and Bent Nodes Map (b)

Table 3: Shortest Time Analysis considering factors

\begin{tabular}{|c|c|c|c|c|c|c|c|c|}
\hline $\begin{array}{l}\text { SL } \\
\text { No. }\end{array}$ & $\begin{array}{l}\text { Outlet } \\
\text { name }\end{array}$ & $\begin{array}{l}\text { Shortest } \\
\text { length }(\mathrm{m})\end{array}$ & $\begin{array}{l}\text { Walking } \\
\text { speed }=60 \\
\mathrm{~m} / \mathrm{min} *\end{array}$ & $\begin{array}{l}\text { Shortest } \\
\text { time } \\
\text { without } \\
\text { bents } \\
\text { (min) }\end{array}$ & $\begin{array}{l}\text { Time } \\
\text { consuming } \\
\text { for bent } \\
\text { node (s) }\end{array}$ & $\begin{array}{l}\text { Time } \\
\text { consuming } \\
\text { for } \\
\text { connectivity } \\
\text { node (s) }\end{array}$ & $\begin{array}{l}\text { Total time } \\
\text { consumed } \\
\text { due to the } \\
\text { bents (min) }\end{array}$ & $\begin{array}{l}\text { Final } \\
\text { shortest } \\
\text { time (min) }\end{array}$ \\
\hline 01 & CS1O9 & 1345 & 60 & 22.40 & $15 * 2=30$ & $9 * 4=36$ & 1.1 & 24 \\
\hline 02 & CS1O5 & 1601 & 60 & 26.70 & $14 * 2=28$ & $5 * 4=20$ & 0.80 & 28 \\
\hline 03 & $\mathrm{CS} 1 \mathrm{O} 7$ & 2575 & 60 & 42.91 & $13 * 2=26$ & $5 * 4=20$ & 0.77 & 44 \\
\hline 04 & CS1O3 & 351 & 60 & 5.85 & $21 * 2=42$ & $14 * 4=56$ & 1.63 & 8 \\
\hline 05 & CS1O15 & 2393 & 60 & 39.88 & $25 * 2=50$ & $8 * 4=32$ & 1.37 & 41 \\
\hline 06 & CS1O11 & 2136 & 60 & 35.60 & $1 * 2=2$ & $6 * 4=24$ & 0.43 & 36 \\
\hline 07 & CS1O19 & 4936 & 60 & 82.26 & $17 * 2=34$ & $10 * 4=40$ & 1.23 & 84 \\
\hline 08 & $\mathrm{CS} 1 \mathrm{O} 21$ & 4374 & 60 & 72.90 & $18 * 2=36$ & $17 * 4=68$ & 1.73 & 75 \\
\hline
\end{tabular}




\begin{tabular}{|c|c|c|c|c|c|c|c|c|}
\hline 09 & CS1O17 & 3625 & 60 & 60.41 & $18 * 2=36$ & $8 * 4=32$ & 1.13 & 62 \\
\hline 10 & CS1O13 & 4721 & 60 & 78.70 & $16 * 2=32$ & $14 * 4=56$ & 1.47 & 80 \\
\hline 11 & $\mathrm{CS} 1 \mathrm{O} 23$ & 3293 & 60 & 54.88 & $18 * 2=36$ & $14 * 4=56$ & 1.53 & 56 \\
\hline 12 & CS1O1 & 5583 & 60 & 93.05 & $19 * 2=38$ & $9 * 4=36$ & 1.23 & 94 \\
\hline 13 & $\mathrm{CS} 2 \mathrm{O} 18$ & 4092 & 60 & 68.20 & $26 * 2=52$ & $15 * 4=60$ & 1.87 & 70 \\
\hline 14 & CS2O16 & 2715 & 60 & 45.25 & $28 * 2=56$ & $15 * 4=60$ & 1.93 & 47 \\
\hline 15 & $\mathrm{CS} 2 \mathrm{O} 12$ & 1812 & 60 & 30.20 & $25 * 2=50$ & $13 * 4=52$ & 1.7 & 32 \\
\hline 16 & $\mathrm{CS} 2 \mathrm{O} 14$ & 2246 & 60 & 37.40 & $19 * 2=38$ & $19 * 4=76$ & 1.9 & 39 \\
\hline 17 & CS2O6 & 746 & 60 & 12.40 & $18 * 2=36$ & $7 * 4=28$ & 1.1 & 14 \\
\hline 18 & $\mathrm{CS} 2 \mathrm{O} 3$ & 518 & 60 & 8.60 & $38 * 2=76$ & $17 * 4=68$ & 2.4 & 11 \\
\hline 19 & $\mathrm{CS} 2 \mathrm{O} 8$ & 1343 & 60 & 22.38 & $22 * 2=44$ & $20 * 4=80$ & 2.1 & 25 \\
\hline 20 & $\mathrm{CS} 2 \mathrm{O} 10$ & 1636 & 60 & 27.30 & $17 * 2=34$ & $12 * 4=36$ & 1.17 & 29 \\
\hline 21 & $\mathrm{CS} 2 \mathrm{O} 1$ & 1993 & 60 & 33.20 & $34 * 2=68$ & $25 * 4=100$ & 2.8 & 36 \\
\hline
\end{tabular}

*Walking speed $3.6 \mathrm{~km} / \mathrm{h}$ or $60 \mathrm{~m} / \mathrm{min}$ (Hasnat, 2016).

Figure 10 shows time to reach to the shelters from the outlets using the shortest routes considering bents along the path for the two shelters.

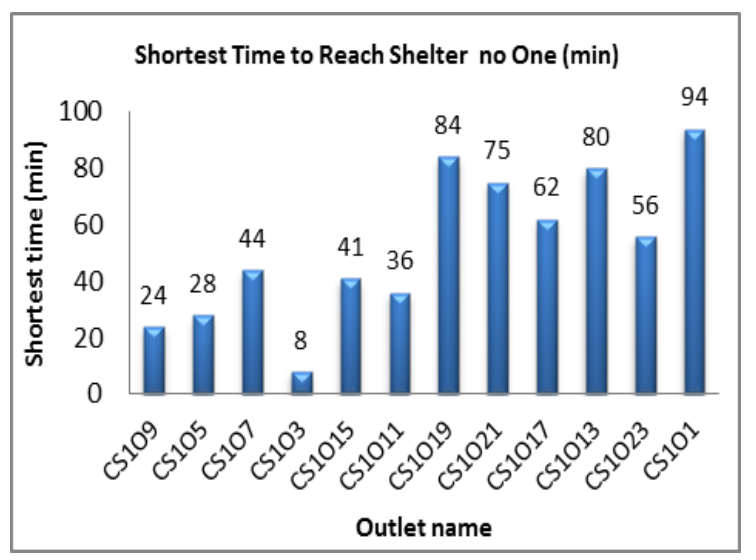

(a)

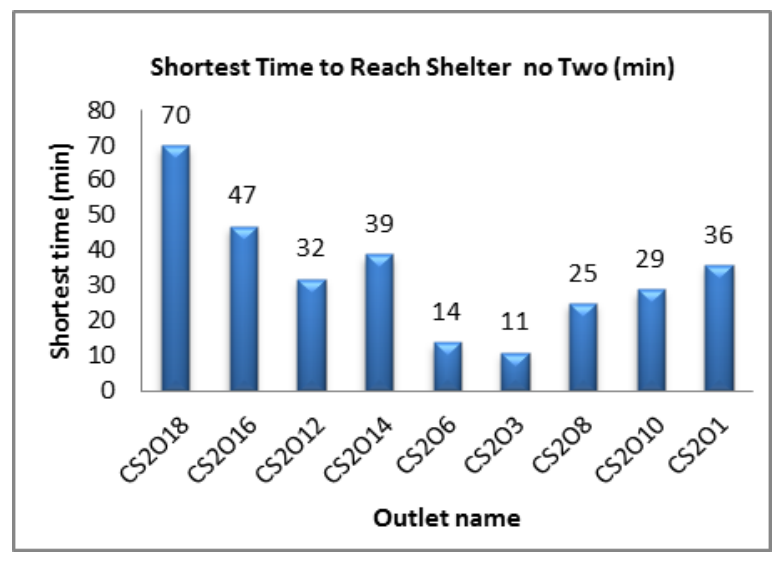

(b)

Figure10: Shortest Time (minutes) from each Outlet 
It has already been mentioned that 1300 people can take shelter in each cyclone shelter. In reality about 4000 people take shelter in each of them and there is always overcrowding as reported by LGED (2014). Maximum 8000 people can use two shelters. On the basis of these data, two scenarios (with 1300 capacity and with 4000 capacity) have been developed to show how many people can be safe from cyclone by taking asylum in the shelters separately.

Figure 11 shows population departure from different outlets for the shelters (having 1300 capacity). In this figure, Green color represents the outlets from where people will be able to take refuge to the shelters since the time for evacuation from these outlets are the shortest. On the other hand, Red color represents the outlets from where people will be unable to take refuge to the shelters since the time for evacuation from these outlets are relatively high that means the shelters will be fully occupied before the people from these outlets reach the shelters.

Figure 11(a) shows the number of people departing from each outlet that cover the capacity (1300 people) of the cyclone shelter number one. It is observed that 1064 people can depart from outlet CS1O3 and only 236 people can depart from outlet CS1O9 to fully occupy shelter one. Similarly for Figure11(b), it is observed that 665 people can depart from outlet CS2O3 and only 635 people can depart from outlet CS2O6 to fully occupy shelter number two.

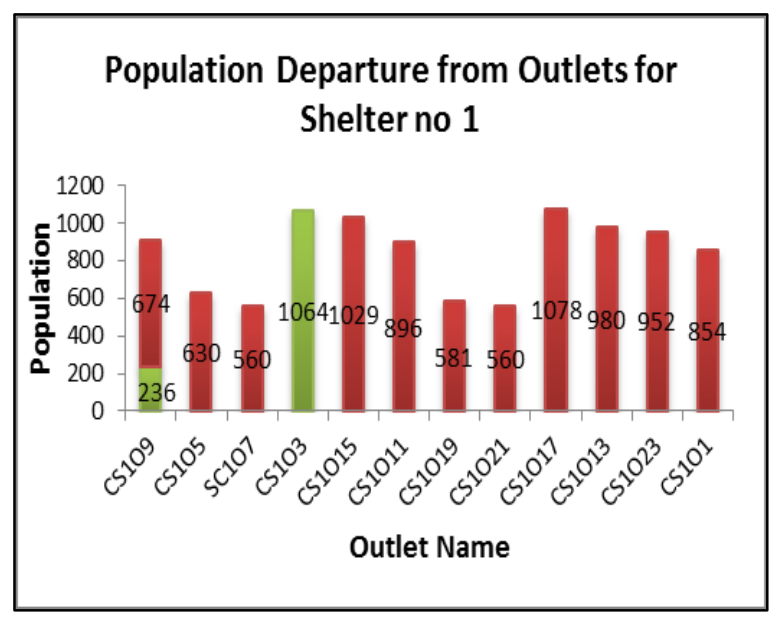

(a)

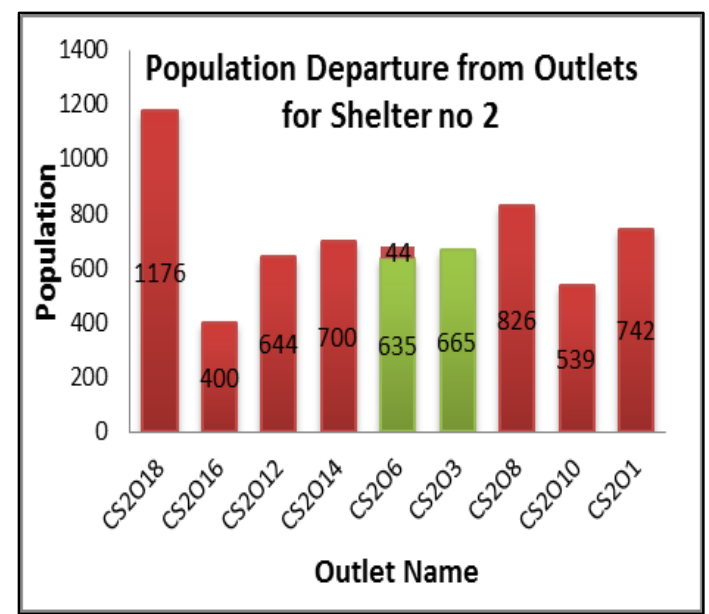

(b)

Figure11: Population from outlets that cover (a) Cyclone Shelter number 1; (b) Cyclone Shelter number 2; when capacity is 1300 people in per shelter.

Figure 12 shows population departure from different outlets for the shelters (having 4000 capacity). Figure 12(a) shows the number of people departing from each outlet that cover the capacity (4000 people) of the cyclone shelter number one. It is observed that 3500 people can depart from outlet CS1O5, CS1O3, CS1O15, CS1O11 and only 500 people can depart from outlet CS1O9 to fully occupy shelter one. Similarly for Figure 12(b), it is observed that 3451 people can depart from outlet CS2O1,CS2O3, CS2O6, CS2O8, CS2O10 and 549 people from CS2O12 to fully occupy shelter number two. 


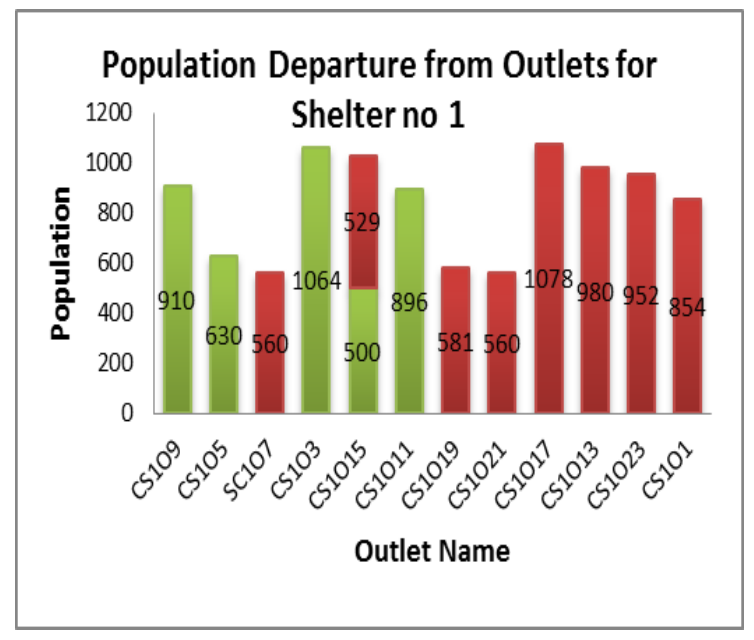

(a)

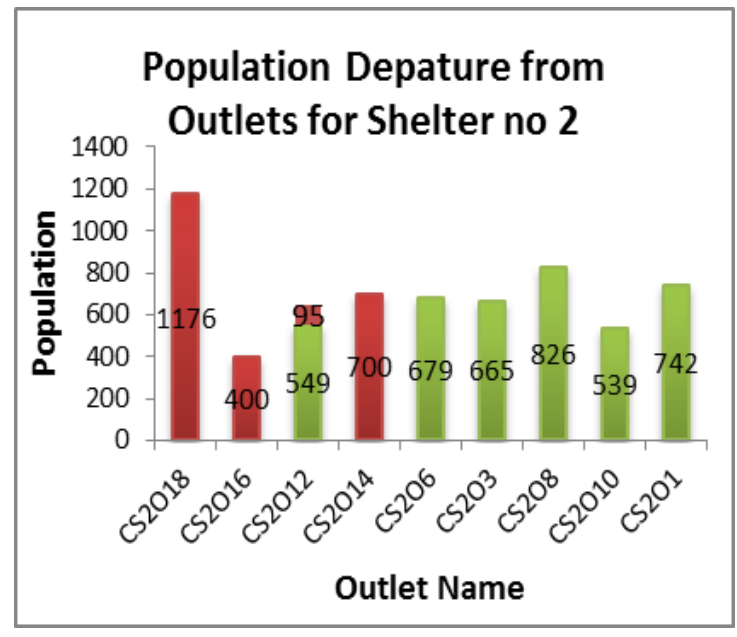

(b)

Figure12: Population from outlets that cover (a) Cyclone Shelter number 1; (b) Cyclone Shelter number 2; when capacity is 4000people in per shelter.

Figure 13 show that having capacity of 1300 people in each cyclone shelters can cover only $12 \%$ of the total population of the union. On the other hand, if the capacity is 4000 persons per shelter, it may cover $36 \%$ of the total population union. From Figure 4, it has been seen that about 5\% (169 infrastructures) of total infrastructures are of low and very low vulnerability that can also be used as shelter during cyclones. These infrastructures include primary schools, mosque, homesteads (high plinth level with sturdy construction, as can be seen in Figure 3a). It has been assumed that average 50 persons can take shelter in these low vulnerable infrastructures covering $39 \%$ of the total population. If the capacity of the cyclone shelter has been considered as 1300 then with low vulnerable infrastructures, the capacity can be increased up to50\% of the total population. And if we consider maximum capacity of the shelters to be 4000, along with low vulnerable infrastructures the capacity can be increased up to $75 \%$ the total population.

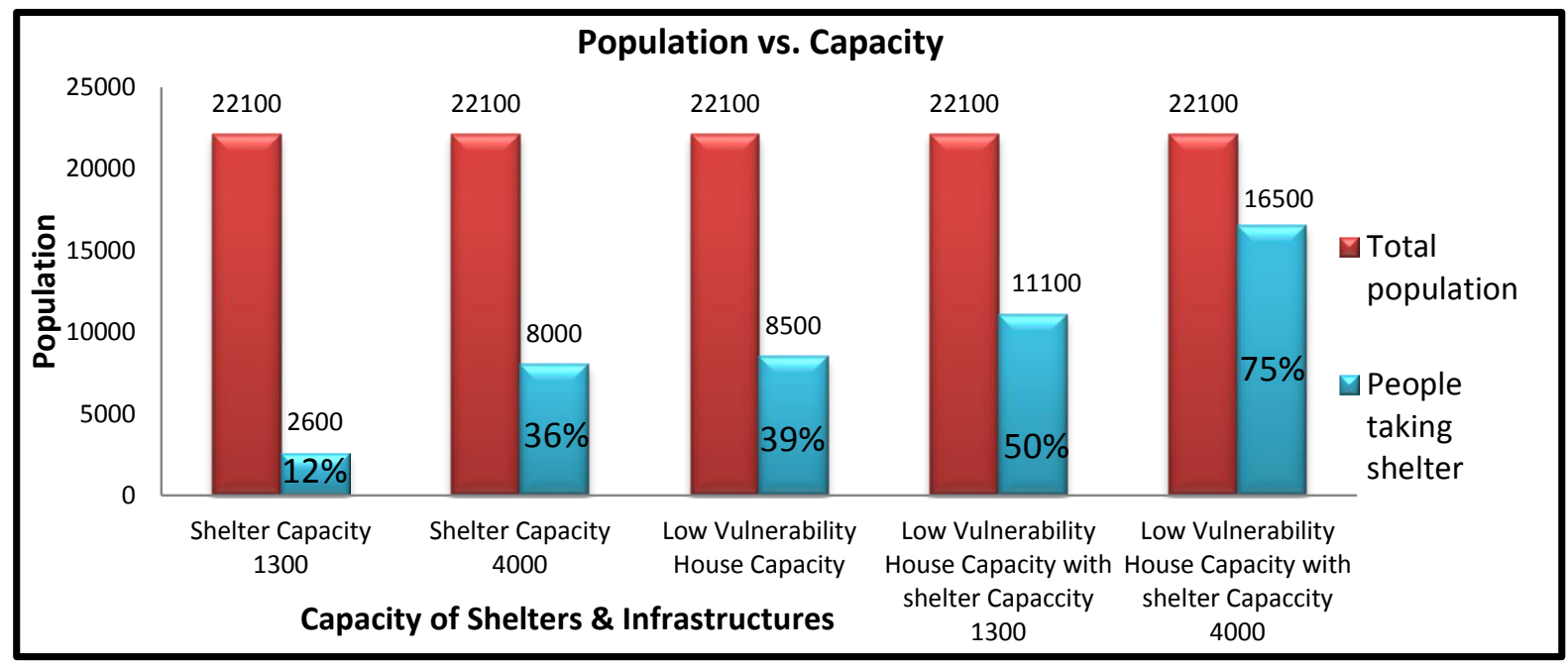

Figure13: Population demand versus capacity under various scenarios

\section{Conclusions}


For a developing country like Bangladesh, the death rate due to cyclone is reducing day by day. The 2007 Cyclone SIDR is not less devastating than the cyclone of 1991 but the death toll has been reduced due to proper early warning dissemination. It is a clear indication that we are improving ourselves in disaster management sector. Hence, death rate could be reduced more if the evacuation has been conducted in a scientific manner. For a proper evacuation, departure route need to be developed and followed. Interview with people affected by cyclones has showed that the number of cyclone shelters in the study area is inadequate. The household condition is also vulnerable. The different existing road types have been considered for the development of evacuation route. More outlets have been suggested in the dense areas from where more people may go to the shelters. Analyzing the shortest distance and time from every outlet to shelters, it has been found that if we consider the shelter capacity to be 1300 , only $12 \%$ of the total population can be accommodated into the shelters. If we consider, the shelter capacity to be 4000 , only $36 \%$ of the total population can be accommodated into the shelters. If we consider the low vulnerable infrastructures, $75 \%$ of the total population can be accommodated. This study provides us an idea how we can manage our population to find out suitable nearby shelters. This study can be used as a role model for coastal belts of Bangladesh for developing a detailed cyclone evacuation plan for the coastal community.

\section{References}

Ahmed, A. U., Haq, S., Nasreen, M., \& Hassan, A. W. R. (2015). Climate change and disaster management. Sectoral Inputs towards the Formulation of the 7th Five Year Plan (2016-2021), 63.

Alam, E., \& Collins, A. E. (2010). Cyclone disaster vulnerability and response experiences in coastal Bangladesh. Disasters, 34(4), 931-954.

Ali, A. (1996). Vulnerability of Bangladesh to climate change and sea level rise through tropical cyclones and storm surges. In Climate Change Vulnerability and Adaptation in Asia and the Pacific (pp. 171-179). Springer.

Ali, S. S., Rahman, M., \& Chowdhury, N. R. (2012). Bangladesh: a sustainable and disaster resilient future. Islamic Relief Worldwide-Bangladesh, Dhaka Google Scholar.

Benavente, J., Del Río, L., Gracia, F. J., \& Martínez-del-Pozo, J. A. (2006). Coastal flooding hazard related to storms and coastal evolution in Valdelagrana spit (Cadiz Bay Natural Park, SW Spain). Continental Shelf Research, 26(9), 1061-1076.

Bern, C., Sniezek, J., Mathbor, G. M., Siddiqi, M. S., Ronsmans, C., Chowdhury, A. M., ... Noji, E. (1993). Risk factors for mortality in the Bangladesh cyclone of 1991. Bulletin of the World Health Organization, $71(1), 73$.

Blaikie, P., Cannon, T., Davis, I., \& Wisner, B. (2014). At risk: natural hazards, people's vulnerability and disasters. Routledge. 
Bukholm, I. R., Husdal, A., Nesland, J. M., Langerød, A., \& Bukholm, G. (2003). Overexpression of cyclin A overrides the effect of p53 alterations in breast cancer patients with long follow-up time. Breast Cancer Research and Treatment, 80(2), 199-206.

Chisty, K. U., Islam, M. K., \& Samad, M. R. B. (n.d.). An Application of GIS for Cyclone Hazard Modelling and Vulnerability Assessment in Coastal Area, a Case Study at Anawara Upazila in Chittagong, Bangladesh.

Choudhury, J. R. (1994). Cyclone shelter and its multipurpose use. In Proceedings of the IDNDR Aichi/Nagoya International Conference (pp. 1-4).

Chowdhury, A. M. R., Bhuyia, A. U., Choudhury, A. Y., \& Sen, R. (1993). The Bangladesh cyclone of 1991: why so many people died. Disasters, 17(4), 291-304.

Cova, T. J., \& Johnson, J. P. (2003). A network flow model for lane-based evacuation routing. Transportation Research Part A: Policy and Practice, 37(7), 579-604.

Dalal, J., Mohapatra, P. K., \& Mitra, G. C. (2007). Locating cyclone shelters: a case. Disaster Prevention and Management: An International Journal, 16(2), 235-244.

Devlin, G. J., McDonnell, K., \& Ward, S. (2008). Timber haulage routing in Ireland: an analysis using GIS and GPS. Journal of Transport Geography, 16(1), 63-72.

Dhar, A. S., \& Ansary, M. A. (2012). Community-based evaluation for the development of a sustainable disaster early warning system. J. of Emergency Management, 10.

Dube, S. K., Rao, A. D., Sinha, P. C., Murty, T. S., \& Bahulayan, N. (1997). Storm surge in the Bay of Bengal and Arabian Sea The problem and its prediction. Mausam, 48(2), 283-304.

Fritz, H. M., Blount, C., Sokoloski, R., Singleton, J., Fuggle, A., McAdoo, B. G., .. Tate, B. (2007). Hurricane Katrina storm surge distribution and field observations on the Mississippi Barrier Islands. Estuarine, Coastal and Shelf Science, 74(1-2), 12-20.

Fritz, H. M., Blount, C., Sokoloski, R., Singleton, J., Fuggle, A., McAdoo, B. G., .. Tate, B. (2008). Hurricane Katrina storm surge reconnaissance. Journal of Geotechnical and Geoenvironmental Engineering, $134(5), 644-656$.

Gupta, B., Gupta, S., Gupta, B., \& Gupta, S. (n.d.). ICT Implementation-GIS Application for Disaster Evacuation. International Journal, 3, 176-180. 
Haider, R., Rahman, A. A., \& Huq, S. (1991). Cyclone'91: an environmental and perceptional study. Bangladesh Centre for Advanced Studies.

Haque, C. E. (1997). Atmospheric hazards preparedness in Bangladesh: a study of warning, adjustments and recovery from the April 1991 cyclone. In Earthquake and Atmospheric Hazards (pp. 181-202). Springer.

Haque, U., Hashizume, M., Kolivras, K. N., Overgaard, H. J., Das, B., \& Yamamoto, T. (2012). Reduced death rates from cyclones in Bangladesh: what more needs to be done? Bulletin of the World Health Organization, 90, 150-156.

Hasnat, M. (2016). Optimum route modeling for emergency response during disastrous situation in densely populated urban area.

Islam, A. S., Bala, S. K., Hussain, M. A., Hossain, M. A., \& Rahman, M. M. (2010). Performance of coastal structures during Cyclone Sidr. Natural Hazards Review, 12(3), 111-116.

Islam, R. M. (2008). Towards institutionalization of global ICZM efforts. Integrated Coastal Zone Management. Research Publishing Services, Singapore, 23.

Khan, M. R., \& Rahman, M. A. (2007). Partnership approach to disaster management in Bangladesh: a critical policy assessment. Natural Hazards, 41(2), 359-378.

Mallick, B. (2014). Cyclone shelters and their locational suitability: An empirical analysis from coastal Bangladesh. Disasters, 38(3), 654-671.

Mallick, B., Rahaman, K. R., \& Vogt, J. (2011). Coastal livelihood and physical infrastructure in Bangladesh after cyclone Aila. Mitigation and Adaptation Strategies for Global Change, 16(6), 629-648.

Mooley, D. A. (1980). Severe cyclonic storms in the Bay of Bengal, 1877-1977. Monthly Weather Review, $108(10), 1647-1655$.

Murray-Tuite, P., \& Mahmassani, H. (2003). Model of household trip-chain sequencing in emergency evacuation. Transportation Research Record: Journal of the Transportation Research Board, (1831), $21-29$.

Murty, T. S., \& El-Sabh, M. I. (1992). Mitigating the effects of storm surges generated by tropical cyclones: a proposal. Natural Hazards, 6(3), 251-273.

Murty, T. S., \& Neralla, V. R. (1992). On the recurvature of tropical cyclones and the storm surge problem in Bangladesh. Natural Hazards, 6(3), 275-279. 
Nateque Mahmood, M., Prasad Dhakal, S., \& Keast, R. (2014). The state of multi-purpose cyclone shelters in Bangladesh. Facilities, 32(9/10), 522-532.

Parvin, G. A., Takahashi, F., \& Shaw, R. (2008). Coastal hazards and community-coping methods in Bangladesh. Journal of Coastal Conservation, 12(4), 181-193.

Paul, Bimal K., Rashid, H., Islam, M. S., \& Hunt, L. M. (2010). Cyclone evacuation in Bangladesh: tropical cyclones Gorky (1991) vs. Sidr (2007). Environmental Hazards, 9(1), 89-101.

Paul, Bimal Kanti. (2009a). Why relatively fewer people died? The case of Bangladesh's Cyclone Sidr. Natural Hazards, 50(2), 289-304.

Paul, Bimal Kanti. (2009b). Why relatively fewer people died? The case of Bangladesh's Cyclone Sidr. Natural Hazards, 50(2), 289-304.

Paul, S. K. (2014). Determinants of evacuation response to cyclone warning in coastal areas of Bangladesh: a comparative study. Oriental Geographer, 55(1-2), 57-84.

Paul, S. K., \& Routray, J. K. (2011). Household response to cyclone and induced surge in coastal Bangladesh: coping strategies and explanatory variables. Natural Hazards, 57(2), 477-499.

Paul, S. K., \& Routray, J. K. (2013). An analysis of the causes of non-responses to cyclone warnings and the use of indigenous knowledge for cyclone forecasting in Bangladesh. In Climate change and disaster risk management (pp. 15-39). Springer.

Quadir, D. A., \& Iqbal, A. M. (2008). Tropical cyclones: impacts on coastal livelihoods. Gland: International Union for Conservation of Nature.

Rana, M. S., Gunasekara, K., Hazarika, M. K., Samarakoon, L., \& Siddiquee, M. (2010). Application of remote sensing and GIS for cyclone disaster management in coastal area: A case study at Barguna district, Bangladesh. International Archives of the Photogrammetry, Remote Sensing and Spatial Information Science, 38(Part 8), 122-126.

Solomon, S., Qin, D., Manning, M., Averyt, K., \& Marquis, M. (2007). Climate change 2007-the physical science basis: Working group I contribution to the fourth assessment report of the IPCC (Vol. 4). Cambridge university press.

Yi, W., \& Özdamar, L. (2007). A dynamic logistics coordination model for evacuation and support in disaster response activities. European Journal of Operational Research, 179(3), 1177-1193. 
Zerger, A., Smith, D. I., Hunter, G. J., \& Jones, S. D. (2002). Riding the storm: a comparison of uncertainty modelling techniques for storm surge risk management. Applied Geography, 22(3), 307-330. 